\title{
Leading trends in state budget regulation: a case of the United States
}

\author{
Tatiana Veynbender \\ Tyumen Industrial University \\ Volodarskogo street 38, 625000 Tyumen \\ Russian Federation \\ e-mail: leotat704@mail.ru \\ Valentina Kashintseva \\ Moscow State University of Civil Engineering - National Research University \\ Yaroslavskoye Shosse 26, 129337 Moscow \\ Russian Federation \\ e-mail: kashintseva_v@mail.ru
}

\begin{abstract}
Maintaining a healthy state budget is a tricky and cumbersome task that any functioning government should undertake. It appears that it takes a true leader when it comes to regulating a balanced budget that is free of losses and unexpected spending.

This paper describes the mechanisms and leading trends of the state budget regulation using an example of the state budget of the United States of America. This example was chosen thanks to the transparency of the available data and the peculiar mechanism the U.S. state budget it prepared and managed.

Our findings and remarks might be useful for any politicians, economists and stakeholders interested in fiscal policy. These people who very often aspire to become leaders of their nations should be aware of pitfalls that the murky waters of doing state budgets usually bring. Therefore, it is important to take a look at how budgeting and financial regulations are done in the leading nations in order to try to use these blueprints in other countries.
\end{abstract}

\section{Introduction}

Regulation of the state budget and the optimization of spending and earnings that are conducted by a government of any functioning country, represents a difficult endeavor that is hurdled by many burdens. Not only that it contains many unexpected gains and losses, but it is also subjected to a certain degree of uncertainty that often makes all principles of textbook financial management irrelevant (see e.g. Trehan and Walsh 2001; Doležal et al. 2015; Kuzmin 2015; Ushakov et al. 2017; Caggiano et al. 2017; or Subačienė et al. 2018). Moreover, it becomes apparent that balanced and healthy state budget is one of the prerequisites of the targeted economic growth and positive economic convergence (Strielkowski and Höschle 2016; Jankelová et al. 2017; or Astrauskaitė and Paškevičius 2018).

In this paper, we will concentrate on the budgetary rules and budget regulation of the United States (U.S.) and will explain in detail how the U.S. state budget is formed and managed throughout the sequence of steps. The example of the U.S was deliberately selected due to its economic position and well-being as well as its balanced budget with various budgetary rules and insurance policies (see Figure 1).

The government of United States budget is defined as an itemized accounting of the received payments such as fees and taxes. It also entails payments made by the state like purchases payments of transfer. A budget deficit is experienced when a nation spends money funds which exceed what it receives in. The reverse of a budget deficit is the budget surplus (McCarthy et al. 2013).

United States of America groups federal spending into three categories that are; discretionary, mandatory and interest on debt spending. Discretionary and compulsory pay of states services as well as programs which citizens rely on. They account for almost $90 \%$ of the federal spending. Interest on debt is defined as the interest that state pays on its accumulated debts. Interest income received by the state is deducted for resources it possesses.

The levels of spending are determined and set by Congress each year. Pentagon and military programs account for a more significant percentage of discretionary spending. Programs such as early childhood education, title grants for marginalized schools as well as Pell grants meant for low-income college students, training as well as scientific research form the major component of discretionary spending (Jordan and Likens 1975). 
Mandatory spending is defined as the spending which the Congress legislates outside the yearly appropriations process. Its major components include Medicare and social security programs. Eligibility rules are used to determine most of the mandatory program's level of spending. It then lays out ways of establishing who is eligible to get benefits from the program.

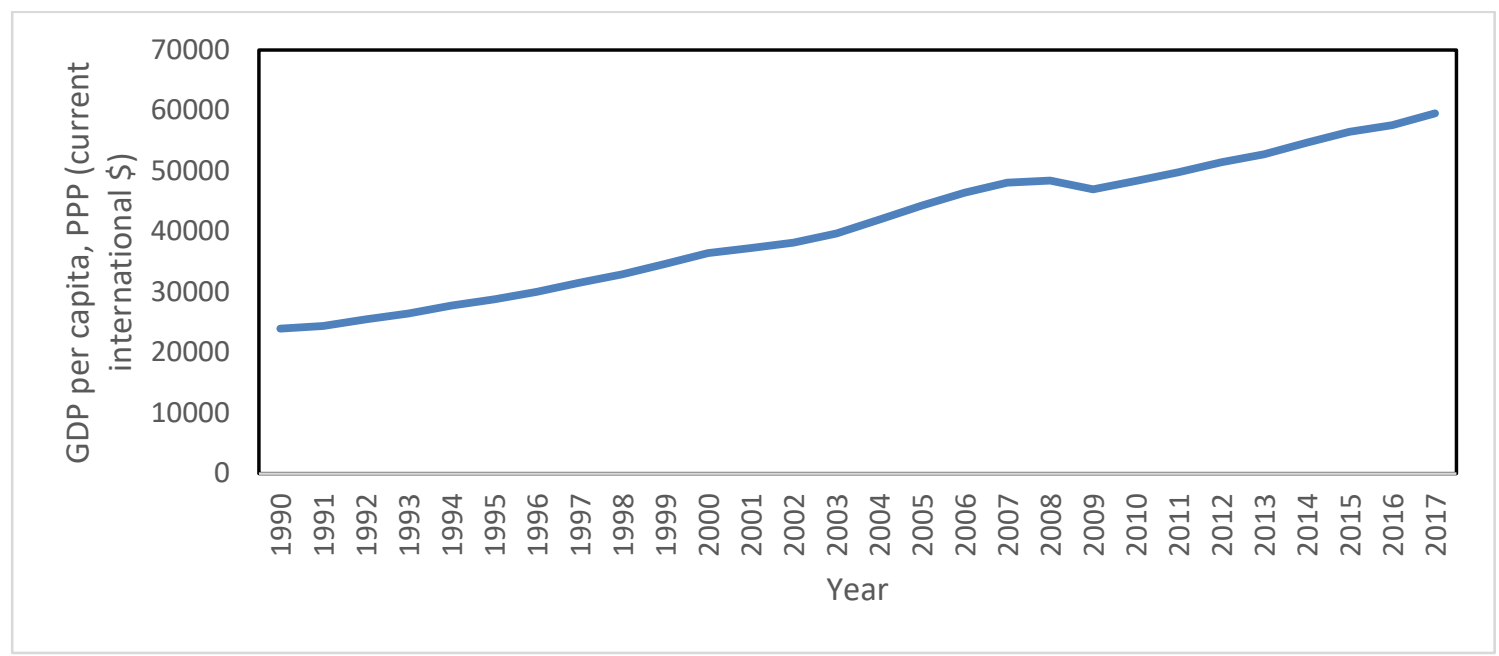

Fig. 1. U.S. Gross Domestic product per capita (1990-2017) Source: World Bank (20180

U.S. Congress periodically reviews the eligibility rules and is allowed to make changes to the existing regulations to exclude or include more individuals. It is also mandated to provide more or less generous benefits to those who have to meet the set criteria, and therefore change the amount spent on the program (Rieger and Leibfried 2003). Mandatory spending forms the most significant percentage of the federal budget when the central state spends resources on compulsory as well as discretionary programs, and the United States writes a heck to offset the costs of the program.

However, spending on tax code makes the Congress has written hundreds of tax breaks into tax code of federal with the aim of encouraging activities that are of great benefit to the community at large, for example, special low tax rates are formulated to promote the growth of a new enterprise. In case the state issues a tax breaks, it opts to surrender tax revenue for specific objective thus both spending and the tax breaks translate to less money in Treasury of U.S. They reflect spending priorities set up by the Congress in the various legislation passed.

\section{Management of the state budget}

Yearly Congress begins preparing the budget for the next financial year (Gelfenbaum et al. 2001). The United States of America's fiscal year starts from October $1^{\text {st }}$ of one calendar year and ends on September $30^{\text {th }}$ of the next year. Preparation starts at the executive arm of the government of U.S. prior when the budget has not been approved. The federal agencies develop budget requests. It is then forwarded White House of management and budget. After that, the office of OMB refers to the agency applications while team develops budget proposal of the president. It is the duty of the president to forwards his budget proposal to Congress in the first month of the financial year. Both the full house and Senate then start to perform its role as stipulated in the constitution. The sequence of steps is shown in Figure 2 that follows.

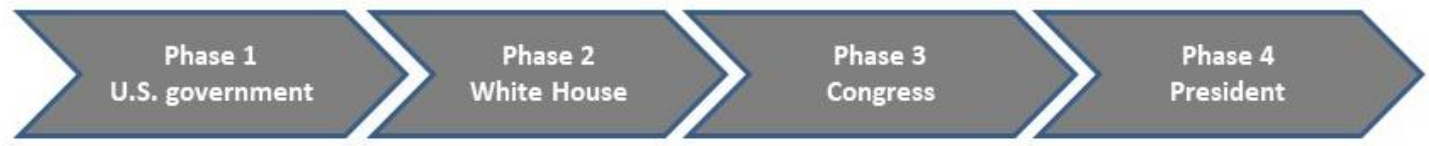

Fig. 2. Management procedure of preparing and maintaining the U.S. state budget Source: Own results 
Authorization of the budget is approved by the congressional authorization committees which must pass in order for the programs to be funded effectively (Arrow at al. 1996). The president of the U.S. must also sign bills providing various agencies with the mandate to allocate resource and run their programs. In the absence of authorization, no single agency can get annually appropriated funding. Authorization of applications can be done at any time of the year.

\section{Regulation of the balanced state budget}

The first role of U.S. Congress in balancing the state budget is to pass a budget resolution defining procedures as well as coming up with limits of spending. The two chambers of the house develop their budget resolution. Finally, their two plans are combined, and the two chambers vote on the similar resolution.

Appropriations bills, the appropriations team for the two chambers share the amount set aside for federal agency funding among twelve subcommittees. The 12 subcommittees are in control of the financing for various roles of the state like energy and water, interior and environment, the defense as well as the agencies involved. The committees carry out hearing in coordination with heads of agencies about their budget requests. Both the upper and the lower house vote on their bills, combine their version and finally vote on the same version of every law. The two, in case it is passed, goes for a signature of the president.

Budget completion, in case the Congress passes, and the head of state appends his signature, the twelve bills by September the $30^{\text {th }}$. The state has the current budget at the appropriate period for the beginning of the next financial year. If the two houses failed to agree on the twelve different bills, it could pass an Omnibus bill. It is characterized by funding for multiple areas, in case the budget is not finalized by the new fiscal year; Congress has to pass a continuing resolution.

The resolution authorizes short-term funding at the previous years' face of states shut down. In the occurrence of the shutdown, the land ceases from issuing of passports and stops NASA operations as well as restricts other functions. The government only resumes standard procedures if the budget process is finally complete. It can also continue with normal activities after the Congress has passed a continuing resolution.

The deficit and debt ceiling, deficit budget is realized in the circumstances that the state collects in taxes in a certain year is less than the amount it spends. The opposite of deficit budget is surplus, and the deficit is reduced by the selling of bonds, bills and notes. The debt ceiling is defined as the minimum debt level which the state permits itself to keep. Both the two houses under the constitution are allowed to vote to increase the debt ceiling. In case the full house and the Senate fail to vote, and the debt exceeds the set limit, the state will not borrow additional funds thus it will not settle its bills.

\section{Reducing governmental debts}

Issuing of bonds, the primary objective of issuing bonds is to get adequate funds. It encourages the government of U.S. to avoid increasing taxes and avails finds to stimulate the economy through public spending. State seeks to stimulate an economy by buying bonds it has issued itself when the economy is in pain like rising level of unemployment. Manipulation of interest rate makes it easy for investors to borrow money. In return, investors acquire goods and services with the money, which creates tax revenues as well as employment opportunities. In the long run, manipulation of interest rate reduces the national debt.

Cutting spending, by instituting deep budget cuts, the state lowers its budget deficit to zero within a short period without necessarily raising taxes. Rising taxes, in case the cash flows increase, and spending persist, the increased revenues create no impact to the difference in the debt level. A bailout, in the circumstance that a country is faced with the deficit budget, it can agree with the rich nations to forgive it its debts. Increasing retirement age, life expectancy has risen in the recent years in U.S. from 70 years to 79. However, the retirement age has decreased by three years, from 65 years to 62. Increasing the retirement age for social security will reduce the obligation of programs at the same motivating individuals to work longer. Thus, larger workforce translates to more taxable income and stable economic growth.

Encouraging rich to spend more on Medicare, to be available for everyone in the state, Medicare requires a significant overhaul. However, the circumstances of attaining universal health care provision with efficiency in cost reduction call for containing cost independently, a particular benefit will have to be minimized. To cover up the lowincome individuals, the state needs to boost premiums as well as cost-sharing for wealthy individuals. Minimizing the Bush tax cuts, in one-year period, almost all tax cuts passed over many years decade will expire. The state should ensure that it eliminates the cost it cannot sustain in the long run in order to stimulate growth. 
Enacting the energy tax, the state is likely not to minimize its debt with spending. Introducing energy tax has the high possibility of creating the positive impact in economic stabilization (Lisin et al., 2018; or Newbery et al., 2018). The State can minimize deficits trough imposing tax on the emission of carbon compounds into the atmosphere. The government can also address climate change without adversely affecting the economy (Toole and Dixon 2005; or Mishra and Singhania 2014). By opening its borders to immigration, the U.S government should open its borders to skilled personnel from across the world to promote the creation of businesses which remit taxes required to reduce the debt. Revamping tax code, to reduce the government's debt as well as jump-start the economy, the Full house and senate house need to pass laws which lower income tax rates. (Kornai 1998). The state needs to reduce spending on defense and increase the retirement age, finally easing off on regulation, reducing regulation will help the State to shrink the national debt.

\section{Conclusions and implications}

Overall, one can see that regulation of the state budget is a task for the true leaders. Not only that it requires many coordinated steps and actions, but it is also subjected to many uncertainties and economic as well as political hurdles.

The United States seem to prosper from the unprecedented economic situation, yet its state budget balancing and regulation is not an easy task to complete. Local stakeholders and policy-makers should be aware of many geopolitical and home-driven issues that might hamper this development.

Moreover, one can see that United States are experiencing some political turmoil that is cased by the confrontations between the Republican President and the mostly pro-Democratic Congress. Moreover, the current U.S. President Donald Trump is waging a trade war on the European Union and China in order to keep his promises spelled out in the election campaign to "make America great again". These steps of the U.S. leadership might lead to serious troubles for the U.S. economy that might affect its state budget and lead to many distortions and unwanted troubles.

All in all, state budget regulation deserves special attention, but it can also be used as a blueprint for other countries wishing to impose healthy financial policies and regulations for the sake of fostering their national economies.

\section{References}

Arrow KJ, Cropper ML, Eads GC, Hahn R (1996). Is there a role for benefit-cost analysis in environmental, health, and safety regulation? Science 272(5259):221-222.

Astrauskaitė I, Paškevičius A (2018) An analysis of crowdfunded projects: KPI's to success. Entrepreneurship and Sustainability Issues 6(1): 3-34. doi: 10.9770/jesi.2018.6.1(2)

Caggiano G, Castelnuovo, E, Figueres JM (2017) Economic policy uncertainty and unemployment in the United States: A nonlinear approach. Economics Letters 151:31-34. doi: 10.1016/j.econlet.2016.12.002

Doležal J, Šnajdr J, Belás J, Vincúrová Z (2015) Model of the loan process in the context of unrealized income and loss prevention. Journal of International Studies 8(1):91-106. doi: 10.14254/2071-8330.2015/8-1/8

Gelfenbaum G, Buijsman MC, Sherwood CR (2001) Coastal evolution and sediment budget at the mouth of the Columbia River, USA. In: Coastal Dynamics' 01 (pp. 818-827). doi: 10.1061/40566(260)84

Jankelová N, Jankurová A, Masár D (2017) Effective management and self-government: current trends. Czech Journal of Social Sciences, Business and Economics 6(2):21-31. doi: 10.24984/cjssbe.2017.6.2.3

Jordan M, Likens GE (1975) An organic carbon budget for an oligotrophic lake in New Hampshire, USA. Internationale Vereinigung für theoretische und Angewandte Limnologie: Verhandlungen 19(2), 994-1003. doi: 10.1080/03680770.1974.11896149

Kornai J (1998) The place of the soft budget constraint syndrome in economic theory. Journal of Comparative Economics 26(1):11-17. doi: 10.1006/jcec.1997.1505

Kuzmin E (2015) "Individual" scaling and overall evaluation of system uncertainty. Modern Applied Science 9(3): 34-45. doi: 10.5539/mas.v9n3p34 
Li L, Li W, Barros AP (2013) Atmospheric moisture budget and its regulation of the summer precipitation variability over the Southeastern United States. Climate Dynamics 41(3-4):613-631. doi: 10.1007/s00382-013-1697-9

Lisin E, Rogalev A, Strielkowski W, Komarov I (2015) Sustainable modernization of the Russian power utilities industry. Sustainability 7(9):11378-11400. doi: 10.3390/su70911378

McCarthy MJ, Gardner WS, Lehmann M. (2013. Implications of water column ammonium uptake and regeneration for the nitrogen budget in temperate, eutrophic Missisquoi Bay, Lake Champlain (Canada/USA). Hydrobiologia 718(1):173-188. doi: 10.1007/s10750-013-1614-6

Mishra US, Singhania D (2014) Contrasting the Levels of Poverty against the Burden of Poverty: An Indian Case. International Economics Letters 3(2):26-35.doi: 10.24984/iel.2014.3.2.1

Newbery D, Pollitt MG, Ritz RA, Strielkowski W (2018) Market design for a high-renewables European electricity system. Renewable and Sustainable Energy Reviews 91:695-707. doi: 10.1016/j.rser.2018.04.025

Rieger E, Leibfried S, Limits to globalization: Welfare states and the world economy. $1^{\text {st }}$ edn. (Wiley, New York, 2003), $416 \mathrm{p}$.

Strielkowski W, Höschle F (2016) Evidence for economic convergence in the EU: The analysis of past EU enlargements. Technological and Economic Development of Economy 22(4): 617-630. doi: $10.3846 / 20294913.2014 .890138$

Subačienè R, Alver L, Brūna I, Hladika M, Mokošová D, Molín J (2018) Evaluation of accounting regulation evolution in selected countries. Entrepreneurship and Sustainability Issues 6(1):139-175. doi: 10.9770/jesi.2018.6.1(11)

Toole J, Dixon P (2005) An inspector calls: the regulation of 'budget'private schools in Hyderabad, Andhra Pradesh, India. International Journal of Educational Development 25(3):269-285. doi: 10.1016/j.ijedudev.2004.09.001

Trehan B, Walsh CE (1991) Testing intertemporal budget constraints: Theory and applications to US federal budget and current account deficits. Journal of Money, Credit and banking 23(2):206-223. doi: 10.2307/1992777

Ushakov D, Bandurina N, Shkodinsky S (2017) Country's Welfare as an Efficiency Factor in Fiscal Policy Promoting Economic Growth. Montenegrin Journal of Economics 13(2):121-127. doi: 10.14254/1800$5845 / 2017.13-2.7$

World Bank (2018). Statistics. https://data.worldbank.org/country/united-states accessed 20 Aug 2018 